\title{
The Level of Indicators of Redox Status in Muscles of Fish from Lakes with Different Trophy
}

\author{
Elżbieta Rusinek-Prystupa ${ }^{1}$, Jacek Rechulicz ${ }^{2 *}$, Katarzyna Ognik ${ }^{1}$ \\ ${ }^{1}$ Department of Biochemistry and Toxicology, University of Life Sciences in Lublin, \\ 13 Akademicka str., 20-950 Lublin, Poland \\ ${ }^{2}$ Department of Hydrobiology and Protection of Ecosystems, University of Life Sciences in Lublin, \\ Dobrzańskiego 37 str., 20-262 Lublin, Poland
}

Received: 3 January 2020

Accepted: 10 September 2021

\begin{abstract}
Oxidative stress in fish is the result of the water quality in the ecosystem and the degree of water pollution. The aim of the study was to determine the oxidative potential in the muscles of selected fish species found in lakes with different trophy status. Values of redox indexes (MDA, Vit. C, SOD and CAT) in the muscle tissue of two native (roach (Rutilus rutilus) and perch (Perca fluviatilis)) and one invasive fish species - brown bullhead (Ameiurus nebulosus) were determined. The differences in redox indexes in muscle tissue of fish from lakes with different trophy status were noted. This indicates differentiated sensitivity of individual fish species to oxidative stress resulting from changes in water quality parameters. The changes in the redox parameters in the tissues of selected fish species were more influenced by the lake trophy than the effect resulting from interspecies differences. Fish from a hypertrophic lake had poorer meat quality due to the greater intensity of oxidation processes in relation to fish from the eutrophic lake. The present study gives the need for further studies that will take into account more fish species and a longer period of time, including changes resulting from the functioning of these reservoirs in different seasons.
\end{abstract}

Keywords: redox status, lake trophy, fish muscles, native fish, invasive fish

\section{Introduction}

Fish are a rich source of wholesome protein, fatty acids (especially unsaturated fatty acids from the omega-3 group), minerals and vitamins $[1,2]$. They are also considered to be bioindicators because they exhibit different sensitivities and responses to environmental

*e-mail: jacek.rechulicz@up.lublin.pl factors that can lead to physiological and biochemical changes [3, 4].

Available literature indicates that fish often have a pronounced oxidative stress as a response to organically and inorganically contaminated aquatic environments (pesticides, phenols, petroleum hydrocarbons, polychlorinated biphenyls, surfactants and heavy metals). Oxidative stress may also indicate that the fish species have reached their limits of adaptation [5-8].

Oxidative stress is the result of an imbalance between the production of free radicals (e.g. reactive oxygen 
species) and antioxidant defense mechanisms in living organisms [9]. Free radicals are dangerous because they destroy cell membranes and damage the structure of enzyme proteins. Superoxide dismutase (SOD), catalase (CAT), glutathione peroxidase (GPx) and glutathione S-transferase (GST) are major antioxidant enzymes and important indicators of oxidative stress. In addition, glutathione (GSH+ GSSG) plays a key role in nonenzymatic antioxidant defense [10, 11].

Aquatic ecosystems are often contaminated with heavy metals such as zinc and copper, the action of which is desired at low concentrations, while at high concentrations, they exhibit toxic effects. In a water environment, the metals, including heavy metals, occur in the form of soluble and insoluble compounds, and accumulate in water and bottom sediments, subsequently becoming distributed in the tissues of aquatic organisms, including fish [12].

The nutrients and other physical and chemical factors of water also have a significant impact on the behavior of redox homeostasis in living organisms. The disturbance of this homeostasis causes intensification of lipid peroxidation. The consequence is the degradation of the structure of fatty acids and proteins, which, in turn, translates into lower nutritional value of meat and shorter preservation of freshness in the process of refrigerated storage [13].

According to Riffel et al. [14], the importance of the antioxidant defense system in response to stress caused by environmental pollution remains a very important motive for further searching for the adaptation possibilities of organisms. In fish, vitamins are part of the first line of antioxidant defense and are involved in maintaining various physiological processes and metabolic reactions. Fish are unable to synthesize vitamin $\mathrm{C}$ due to lack of L-gulonolactone oxidase, the enzyme responsible for its synthesis in de novo. Vitamin $\mathrm{E}$ is involved in the immune response and one of its main physiological functions is the protection of the membrane against oxidative damage associated with the production of free radicals. In fish muscle, it plays an important role as an antioxidant in vivo [2].

Available scientific research on the redox potential in fish focuses on a limited number of model species, mainly from the salmonid family and the cyprinids. Information about other species are limited $[15,16]$.

Due to the fact that there is not much information available in the literature on the impact of lake water quality parameters on changes in fish meat redox potential, this paper attempts to determine: 1) whether parameters characterizing the state of water quality in lakes have an impact on the redox potential in fish muscles; 2) whether the level of redox status indicators of various fish species (perch, roach and brown bullhead) occurring in lakes with different trophy depends on the species and the settled lake.

\section{Materials and Methods}

\author{
Study Area
}

Lake Syczyńskie is a small (5.6 ha), shallow (2.9 m), hypertrophic water body located in the ŁęczyńskoWłodawskie Lakeland (51 $\left.17^{\prime} 12^{\prime \prime} \mathrm{N}, 23^{\circ} 14^{\prime} 16^{\prime \prime} \mathrm{E}\right)$. The lake is located in the village of Syczyn and its northern and western shore is directly adjacent to private plots properties. In relation to its area, the Syczyńskie Lake have a large catchment area of about 460 ha and over $86 \%$ of it is used for agriculture (arable fields, meadows and pastures).

Values characterizing the parameters of its water indicate extreme hypertrophy. According to the classification of Rücker et al. [17], Syczyńskie lake is a "Planktothrix-lake". As shown in Wiśniewska et al. [18], in the summer and fall, P. agardhii comprises approx. $96 \%$ of the potentially toxic Cyanobacteria in this lake. Moreover, several years of observation of its fish community has revealed a variation of species dominance that depends on the year and season. In addition, the fish fauna is characterized by low values of indices of diversity [19].

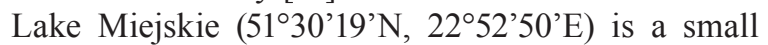
(45.8 ha) and shallow water reservoir (max depth $2.2 \mathrm{~m}$, mean depth $1.3 \mathrm{~m}$ ) [20]. The lake is located near the Ostrów Lubelski city and its catchment area consists of arable fields (approx. 75\%) as well as meadows and pastures (approx. 20\%) [20]. Lake Miejskie is located approx. $50 \mathrm{~km}$ from Lake Syczyńskiego and is characterized by 2.5 times smaller catchment area and different fishery management and angling pressure. In the summer season the lake is intensively used for recreation. Biomanipulation in the reservoir was carried out in 2007 and has resulted in a change in the fish community, and, over time, improvement in the ecological condition of the lake [21, 22].

\section{Analysis of Water Parameters and Fish Sampling}

The water samples for chemical analysis were taken on a monthly basis from June to August in the years, 2014 and 2015. The following physical and chemical factors were examined: temperature, $\mathrm{pH}$, electrical conductivity, total organic carbon (TOC), chlorophyll $a$, ammonium-nitrogen, nitrate-nitrogen and phosphates. Temperature, electrical conductivity and $\mathrm{pH}$ were recorded in situ using a multiparametric probe (YSI 556, USA). Total organic carbon was determined by employing a multiparametric UV analyzer (Secomam, France), and the remaining factors were analyzed in the laboratory [23]. Chlorophyll $a$ was determined by spectrophotometric analysis of the acetone extract of the algae [24].

Fish for analysis were caught using multi-mesh gill nets $(6.25-75 \mathrm{~mm})$ [25]. Fishing by nets in both lakes 
Table 1. Total length (Tl) and body mass (W) of analyzed fish from studied lakes.

\begin{tabular}{|c|c|c|c|c|c|c|c|c|c|c|}
\hline \multirow{2}{*}{ Lakes } & \multirow{2}{*}{ Species } & & \multicolumn{4}{|c|}{ Total length (Tl) (in cm) } & \multicolumn{4}{|c|}{ Body mass (W) (in g) } \\
\hline & & $\mathrm{N}$ & Means & Std. Dev. & Min. & Max. & Means & Std. Dev. & Min. & Max. \\
\hline \multirow{3}{*}{ Syczyńskie } & Perch & 12 & 21.76 & 0.90 & 20.80 & 23.40 & 154.90 & 28.70 & 106.70 & 223.00 \\
\hline & Roach & 16 & 18.22 & 0.96 & 17.30 & 19.60 & 78.08 & 7.88 & 68.00 & 89.00 \\
\hline & Brown bullhead & 16 & 19.63 & 2.34 & 15.50 & 23.80 & 137.25 & 59.09 & 53.00 & 252.00 \\
\hline \multirow{3}{*}{ Miejskie } & Perch & 12 & 24.03 & 2.03 & 22.00 & 27.80 & 208.60 & 62.89 & 123.00 & 300.00 \\
\hline & Roach & 16 & 18.96 & 1.01 & 18.00 & 21.80 & 94.94 & 43.88 & 64.00 & 244.00 \\
\hline & Brown bullhead & 16 & 20.41 & 1.49 & 18.60 & 22.80 & 106.81 & 22.64 & 74.00 & 142.00 \\
\hline
\end{tabular}

were conducted in summer 2014 and 2015 years. All collected fish were identified to species and weighed (W) to nearest $0.1 \mathrm{~g}$, while total length $(\mathrm{Tl})$ was taken to the nearest $1 \mathrm{~mm}$. Information about the number of fish used in the study, their total length and body mass in Table 1 were presented.

\section{Analysis of Oxidation-Reduction Parameters}

Muscle tissue samples were collected above the lateral line. From each fish, nine $1 \mathrm{~g}$ samples were collected after skinning. The muscle samples were first stored at $-20^{\circ} \mathrm{C}$ for a period of 2 weeks and then homogenized in buffers according to the applicable methodological procedures. Muscle homogenates was also examined to measure the activity of superoxide dismutase (SOD) by spectrophotometry, using the adrenaline assay method by Greenwald [26]. The SOD activity is determined by measuring the rate of auto-oxidation of adrenaline at $30^{\circ} \mathrm{C}$ on the basis of the increase of absorbance at $320 \mathrm{~nm}$ (which corresponds to the monitoring of the increase of concentration of various products of adrenaline oxidation). The activity of catalase (CAT) was also established, following the Bartosz [27] method. This analysis consisted in the measurement of the substrate decomposition rate (hydrogen peroxide) catalyzed by this enzyme.

In determining the antioxidant status parameters, the content of vitamin $\mathrm{C}$ (vit. C) was assessed calorimetrically in a reaction with 2,6-dichlorophenolindophenol, following the method of Omaye et al. [28]. In addition, muscle homogenates were analyzed for levels of malondialdehyde (MDA) the lipid peroxidation products that are the end product of tissue lipids oxidation, in accordance to the procedure of Salih et al. [29]. The method is based on a thiobarbituric acid (TBA) reaction with lipid peroxidation end products in an acid environment, with the increased temperature generating a colored adduct. To eliminate quantities of complex series of adducts from TBA, the assay is run in the presence of inhibitors, e.g. BHT.

\section{Statistical Analysis}

Prior to statistical analyses, all data were checked for normality (Shapiro-Wilk test) and homogeneity of variances. To compare the physical and chemical parameters of both lake waters, one-way analysis of variance (ANOVA) was used. Statistical differences in the values of redox status indicators in fish muscle from both lakes were ascertained using a two-factor analysis of variance (2-ways ANOVA with interaction) (factor 1: lake, factor 2: fish species, interaction: lake $\mathrm{x}$ fish species). The statistical analyses were carried out with Statsoft Statistica software, with a significance level of $\mathrm{p} \leq 0.05$.

In order to compare the redox potential of fish species (perch, roach and brown bullhead) from both lakes, principal component analysis (PCA) was applied, using Canoco 4.5 Software.

\section{Results and Discussion}

Information on antioxidant protection in fish is modest, although fish are constantly exposed to environmental stressors, including oxidative stress [30]. The physiology of stress in fish has been studied in species such as rainbow trout, zebrafish and common carp [31-33]. Due to the fact that fish are mostly perennial organisms, the negative effects of the environment in their organisms are often difficult to assess [27]. Many of them can manifest itself only after a long period of time. In addition, organisms, including also fish, tend to adapt [34].

Three species of fish, two native ones, i.e. roach (Rutilus rutilus) and perch (Perca fluviatilis), and an invasive alien species, the brown bullhead (Ameiurus nebulosus) for the analysis were selected. These species are diverse in terms of biology, but all have high tolerance to habitat conditions. Roach and perch are ubiquitous species occurring in almost all types of water reservoirs. At the same time, these species, due to the varied food they eat, represents different trophic levels. The roach is an omnivorous species and its diet includes 
both planktonic organisms as well as aquatic plants and invertebrate fauna. The perch, on the other hand, is a predatory species which, when it in size approx. $14-16 \mathrm{~cm}$ begins to eat fish [35]. The brown bullhead is an alien and invasive species that should be removed from natural aquatic ecosystems. It is an omnivorous species [36], very resistant to many environmental factors and having stable populations in many water reservoirs in the region [37]. The knowledge on the immune resistance and redox stress of selected fish species is very modest and there is no such information in the available references.

The mechanisms for greater tolerance under certain environmental conditions can occur in two different ways. First, through physiological acclimatization, and second, through genotypic adaptation. An example would be fish, which is less sensitive to chronic stressors and therefore may be more efficient under stressful environmental conditions. This advantage may be effective due to the heritability of the trait. Acclimatization occurs in fish individually, where they become accustomed to a different environment through the physiological expression of resistant phenotypes. In turn, adaptation takes place on a population scale, where genetic changes allow for the occurrence of genotypes with better performance in a specific environment [38].
The studies indicated that the physical and chemical parameters of water from both lakes were different. In total, for water from Lake Syczyńskie, we recorded higher values of parameters responsible for the eutrophication of the lake. Herein, significantly higher values ( $\mathrm{M}-\mathrm{W} \mathrm{U}$ test, $\mathrm{p}<0.05)$ were noted for electrical conductivity, $\mathrm{P}-\mathrm{PO}_{4}, \mathrm{P}$ tot, chlorophyll $a$ and total suspended solids (TSS) (Table 2).

The basic sources of pollution from the lake catchment areas that increase eutrophication of freshwaters are agriculture, animal production and households, especially those not connected to the sewage system. Excess amounts of phosphorus compounds are the cause of blooms in water reservoirs and of the high concentrations of chlorophyll-a, which is an index of the development of phytoplankton biomass [39-41]. Nevertheless, the degree of eutrophication of reservoirs is directly related to the morphometric conditions of the water bodies and the size of the catchment basin. The object of our study, Lake Syczyńskie, is a small, shallow reservoir, with a catchment of about 500 ha holding a large share of arable land (65.6\%). This contributes to increasing susceptibility to eutrophication [42, 43]. According to Pajewski [44], the manner of area usage located within the basin mainly affects the quality of water in the lake. As a consequence, the increase in lake trophy may lead to changes in the structure of

Table 2. Characteristics of water indicators (means \pm SD) of studied lakes (mean values for 2014-2015 years).

\begin{tabular}{|c|c|c|c|}
\hline Parameter & Unit & Syczyńskie Lake & Miejskie Lake \\
\hline $\mathrm{T}$ & ${ }^{\circ} \mathrm{C}$ & $15.99 \pm 7.41$ & $13.58 \pm 6.91$ \\
\hline $\mathrm{pH}$ & - & $7.44 \pm 0.58$ & $7.87 \pm 0.45$ \\
\hline TST & $\mathrm{mg} \mathrm{dm}^{-3}$ & $13.02 \pm 5.62$ & $8.49 \pm 5.32$ \\
\hline $\mathrm{EC}$ & $\mu \mathrm{S} \mathrm{cm}-1$ & $547.33 * \pm 32.34$ & $144.47 \pm 12.40$ \\
\hline $\mathrm{O}_{2}$ & $\mathrm{mg} \mathrm{dm} \mathrm{m}^{-3}$ & $10.94 \pm 3.22$ & $10.25 \pm 1.17$ \\
\hline$\% \mathrm{O}_{2}$ & $\%$ & $106.66 \pm 19.65$ & $99.42 \pm 20.21$ \\
\hline $\mathrm{N}-\mathrm{NH}_{4}$ & $\mathrm{mg} \mathrm{dm} \mathrm{m}^{-3}$ & $0.20 \pm 0.01$ & $0.38^{*} \pm 0.21$ \\
\hline $\mathrm{N}-\mathrm{NO}_{3}$ & $\mathrm{mg} \mathrm{dm} \mathrm{m}^{-3}$ & $0.33 \pm 0.16$ & $0.21 \pm 0.14$ \\
\hline $\mathrm{N}-\mathrm{NH}_{4}+\mathrm{N}-\mathrm{NO}_{3}$ & $\mathrm{mg} \mathrm{dm}{ }^{-3}$ & $0.53 \pm 0.15$ & $0.58 \pm 0.33$ \\
\hline P-PO ${ }_{4}$ & $\mathrm{mg} \mathrm{dm}^{-3}$ & $0.29^{*} \pm 0.11$ & $0.05 \pm 0.04$ \\
\hline Ptot & $\mathrm{mg} \mathrm{dm}{ }^{-3}$ & $0.46^{*} \pm 0.07$ & $0.07 \pm 0.05$ \\
\hline Chlor & $\mu \mathrm{g} \mathrm{dm}-3$ & $70.28 * \pm 42.40$ & $33.16 \pm 14.05$ \\
\hline TSS & $\mathrm{mg} \mathrm{dm}^{-3}$ & $24.37 * \pm 2.56$ & $7.61 \pm 7.67$ \\
\hline TOC & $\mathrm{mg} \mathrm{dm}^{-3}$ & $6.92 \pm 0.92$ & $7.73 \pm 1.16$ \\
\hline $\mathrm{NO}_{3}$ & $\mathrm{mg} \mathrm{dm}^{-3}$ & $<0.2 \pm 0.01$ & $<0.2 \pm 0.01$ \\
\hline SUR & $\mathrm{mg} \mathrm{dm}^{-3}$ & $3.66 \pm 0.73$ & $4.07 \pm 0.61$ \\
\hline COD & $\mathrm{mg} \mathrm{O}_{2} \mathrm{dm}^{-3}$ & $17.05 \pm 2.00$ & $18.96 \pm 2.91$ \\
\hline BOD & $\mathrm{mg} \mathrm{O}_{2} \mathrm{dm}^{-3}$ & $9.55 \pm 1.27$ & $10.90 \pm 1.68$ \\
\hline
\end{tabular}

*-significant differences at $\mathrm{p} \leq 0.05$ 
groups of plant organisms, and, most importantly, in the ichthyofauna [19], and, as a consequence, to the intensification of oxidative stress in fish $[8,45]$.

The values of redox parameters in fish muscles varied depending on the lake and fish species $(\mathrm{p}<0.001)$, but differences due to the interaction of lake vs. fish species were noted as well. In the fish from Lake Syczyńskie, significantly higher MDA contents were

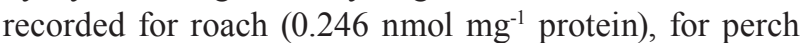
and brown bullhead $\left(0.32 \mathrm{nmol} \mathrm{mg}^{-1}\right.$ protein for each). In addition, higher CAT activity for roach $\left(4.310 \mathrm{U} \mathrm{mg}^{-1}\right.$ protein) and perch (6.31 $\mathrm{U} \mathrm{mg}^{-1}$ protein) were noted (M-W U test, $\mathrm{p}<0.0001$ ). Moreover, the fish from Lake Miejskie revealed higher content of Vit. C and SOD activity (M-W U test, $\mathrm{p}<0.0001$ ) (Fig. 1).

In comparing the differences in the values of redox status indicators between fish species in each lake, significant differences were observed. For fish from Lake Syczyńskie, in all the studied parameters, there was a difference depending on the species. Herein, we saw significantly higher values for perch and brown bullhead in the case of MDA content and CAT activity (Fig. 1a and 1d), and for roach and perch in the case of Vit. C content and SOD activity (Fig. 1(b-c)). In the case of fish from Lake Miejskie we recorded significant difference only between the content of MDA and the activity of SOD (M-W U test, p <0.0001) (Fig. 1(a-d)).

Based on the obtained results, oxidative stress in the fish organism is affected by the living environment, especially trophy. That the degree of eutrophication of lakes may affect the quality of fish tissues is evidenced by increases in the content of MDA and CAT activity in fish from the hypertrophic Lake Syczyńskie. As reported by Mohanty and Samanta [46], CAT plays a vital role in scavenging the $\mathrm{H}_{2} \mathrm{O}_{2}$ produced through dismutation of superoxide anion radicals $\left(\mathrm{O}_{2}{ }^{-}\right)$by super-oxide dismutase (SOD). According to some authors, the CAT-SOD system can be treated as the first line of defense against anti-oxidative stress [47, 48]. In addition, as shown by the studies of Carvalho et al. [30] on the liver and muscle of Oreochromis niloticus, among others, SOD and CAT could be considered
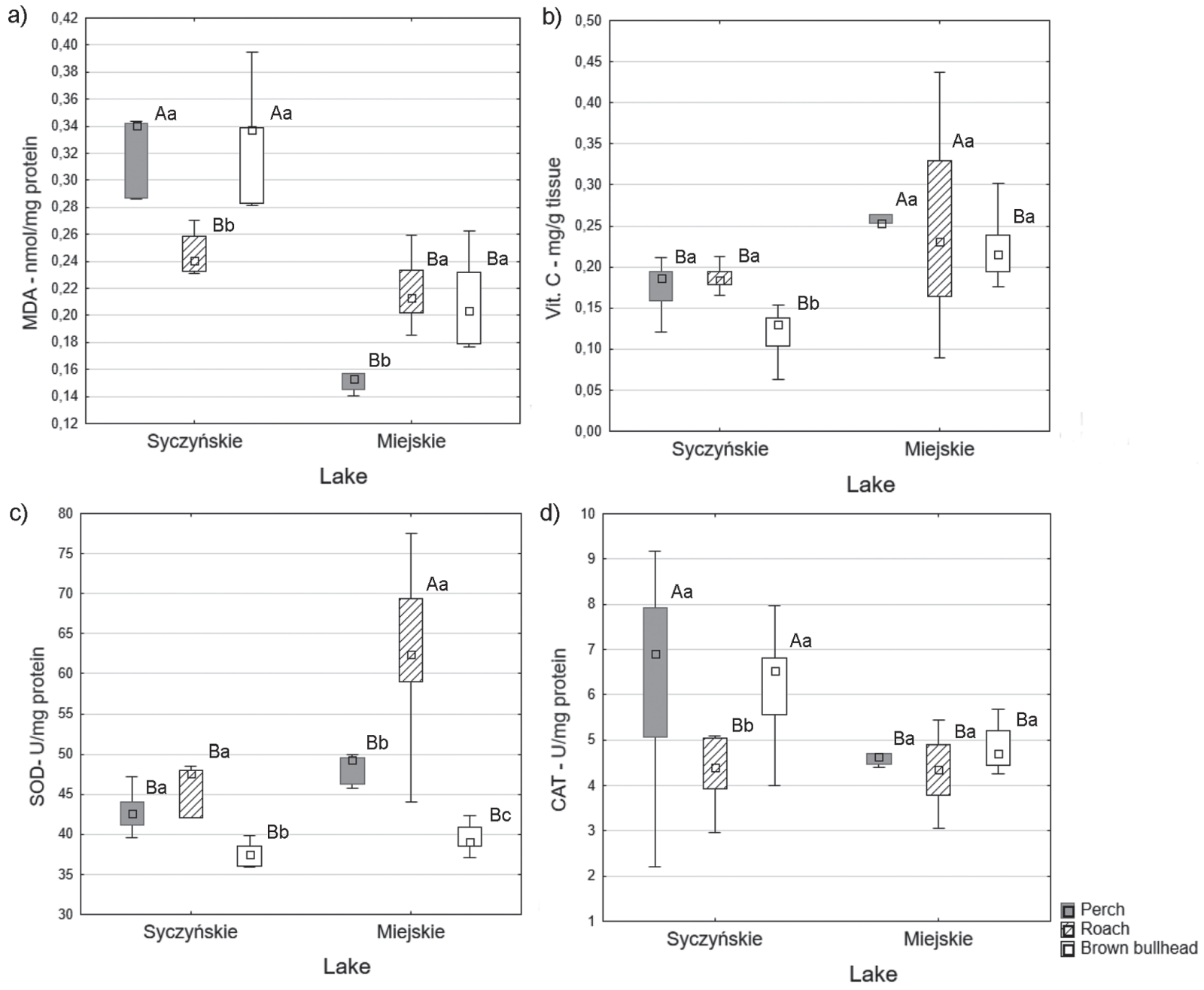

Fig. 1. Characteristic of values of pro-oxidative and antioxidative parameters of muscles of perch, roach and brown bullhead for two lakes with different trophic status; signs on the graph: whiskers - min and max values, box -25 th -75 th percentile, point - median, values signed the differ uppercase letter - statistically significant differences between species and the lake; values signed the differ lowercase letters - statistically significant differences within the lake 
as potential candidates for biomarkers of toxicity of contaminants in fish tissues.

In our results, we recorded higher values of malondialdehyde (MDA) in the fish muscles. This may indicate that oxidative stress induces lipid peroxidation in fish muscle tissue. As a result of the lipid peroxidation process, redox balance is disturbed. This is notable in the fish of hypertrophic Lake Syczyńskie. What is more, we saw in the muscle tissue of the brown bullhead, an increase in catalase enzyme activity (CAT) that is correlated with a decrease in the level of non-enzymatic antioxidants (vitamin C). This must be caused by stimulation of the antioxidant mechanisms to defend against the reactive oxygen form (ROS) [4, 49, 50]. Enzymatic antioxidant protection is a key component of the biochemical system that allows survival of species during oxidative stress [51]. The abundance of vitamin $\mathrm{C}$ in tissues depends on several factors: past diseases, diet, lifestyle, as well as the intensification of metabolic processes in the body. According to Ciszewski et al. [52], the range of values of redox indicators is built upon many factors, including the species, age, sex, physiological condition, as well as the season and abundance of the habitat in food.

In our study, we used fish species commonly found in freshwaters waters and which vary in terms of food preferences: omnivorous-roach and predator-perch. In addition, we studied a third species, the invasive brown bullhead. This has been present in Poland's waters for about 100 years and has very varied food preferences, being omnivorous or predatory [36]. According to available literature [53, 54], brown bullhead is characterized by having very high resistance to poor living conditions and to pollution. In addition, it can survive drops in oxygen content even to $0.2 \mathrm{mg}$ $\mathrm{L}^{-1}$. In contrast, species such as roach and perch hold moderate environmental requirements [55]. Hence, the slightly higher MDA content in the muscles of roach from Lake Miejskie, are comparable to the results obtained for the brown bullhead.

Smal et al. [56] and Solis [43] state that Lake Syczyńskie is exposed to surface pollution originating from the lake catchment, and especially to the inflow of anthropogenic pollution from the used agricultural fields. Intensive agricultural production is one of the sources of soil contamination with heavy metals. These are found in the composition of many fertilizers, especially in phosphate fertilizers [57]. The effect of heavy metal pollution on the oxidative stress and osmoregulatory damage of fish was confirmed by the study by Kaya and Akbulut [50]. These were conducted on the brain tissue and gills of tilapia in Mozambique that are exposed to lead, and in the tissues of these fish, a high level of TBARS was noted, which is a commonly used indicator of lipid oxidation status. Hermenean et al. [58] conducting a study on the impact of heavy metal aquatic contamination on fish also saw high levels of TBARS in the liver of chub.

Table 3. Spearman Rank Order Correlation for redox parameters and physical-chemical parameters of water from studied lakes.

\begin{tabular}{|c|c|c|c|c|c|c|c|c|}
\hline \multirow{2}{*}{ Parameters } & \multicolumn{4}{|c|}{ Syczyńskie Lake } & \multicolumn{4}{|c|}{ Miejskie Lake } \\
\hline & MDA & Vit. C & SOD & CAT & MDA & Vit. C & SOD & CAT \\
\hline $\mathrm{T}$ & -0.401 & $0.862^{*}$ & 0.195 & -0.042 & -0.068 & -0.221 & -0.383 & 0.570 \\
\hline $\mathrm{pH}$ & 0.445 & 0.350 & 0.262 & 0.168 & -0.288 & 0.211 & -0.254 & 0.119 \\
\hline TST & 0.361 & 0.333 & 0.127 & 0.050 & 0.008 & 0.272 & -0.415 & 0.110 \\
\hline $\mathrm{EC}$ & -0.453 & -0.325 & -0.433 & -0.065 & -0.162 & -0.221 & $-0.681^{*}$ & $0.732 *$ \\
\hline $\mathrm{O}_{2}$ & 0.420 & $-0.983^{*}$ & -0.380 & -0.034 & -0.220 & 0.228 & 0.170 & -0.170 \\
\hline$\% \mathrm{O}_{2}$ & $0.849^{*}$ & -0.600 & -0.025 & 0.134 & -0.246 & -0.009 & -0.314 & 0.415 \\
\hline $\mathrm{N}-\mathrm{NH}_{4}$ & $-0.966^{*}$ & 0.483 & -0.076 & -0.521 & -0.195 & 0.114 & 0.331 & -0.195 \\
\hline $\mathrm{N}-\mathrm{NO}_{3}$ & $0.815^{*}$ & -0.400 & -0.152 & 0.387 & -0.059 & 0.448 & 0.246 & -0.314 \\
\hline $\mathrm{TNN}$ & $0.672 *$ & -0.283 & -0.203 & 0.168 & -0.271 & 0.334 & 0.339 & -0.271 \\
\hline $\mathrm{P}-\mathrm{PO}_{4}$ & -0.412 & -0.300 & -0.279 & -0.185 & 0.314 & -0.220 & 0.059 & 0.008 \\
\hline Ptot & $-0.740^{*}$ & 0.200 & -0.380 & 0.017 & 0.042 & 0.097 & 0.534 & -0.263 \\
\hline Chlor & 0.513 & 0.333 & 0.447 & 0.118 & -0.144 & -0.466 & 0.331 & 0.314 \\
\hline TOC & -0.487 & -0.333 & -0.295 & -0.261 & 0.221 & -0.221 & 0.596 & -0.340 \\
\hline SUR & -0.470 & -0.294 & -0.170 & -0.102 & -0.034 & 0.193 & 0.576 & -0.644 \\
\hline COD & -0.464 & -0.310 & -0.258 & -0.278 & 0.102 & -0.203 & 0.426 & -0.306 \\
\hline BOD & -0.487 & -0.333 & -0.295 & -0.261 & 0.221 & -0.221 & 0.596 & -0.340 \\
\hline
\end{tabular}

*-significant differences at $\mathrm{p} \leq 0.05$ 
Our research results show a wide spectrum of differences between eutrophic (Miejskie) and hypertrophic (Syczyńskie) lakes. These we found are associated with higher or lower activity of redox indicators in fish tissues. Past research has revealed notably upward trends in parameter values and higher oxidative stress in polluted waters when compared with cleaner water reservoirs [59]. In the tissues of fish inhabiting Lake Miejskie, we found higher vitamin C content, SOD activity and lower MDA and CAT activity. In such fish, the increase in SOD activity was probably recorded during the activation of antioxidant defense mechanisms. However, such situations also commonly see an increase in the content of MDA and the activity of CAT [60]. Since there has been no increase in the above-mentioned oxidation parameters, it should be recognized that the condition of the fish environment does not induce such processes in the fish body. Similarly, McFarland et al. [61] reported that the activity of the catalase was lower in contaminated river waters, when compared to sites less polluted. In addition, Shen et al. [62] on assessing the activity of catalase in the liver of carp living in a polluted environment, found a decrease in the activity of catalase due to the fluctuation of superoxide radicals. Accordingly, the presence of heavy metals (which are mainly taken up by the gills) may have an inhibitory effect on the activity of catalase.

Table 3 shows the analysis of correlation between redox indicators and physical and chemical parameters of water showed that Lake Syczyńskie held definitely more significant dependencies. Significant positive correlations were indicated between temperature $(\mathrm{T})$ and the content of Vit. C $(r=0.862, p<0.001)$, and between oxygen saturation $\left(\% \mathrm{O}_{2}\right)$, nitrate nitrogen $\left(\mathrm{N}-\mathrm{NO}_{3}\right)$, total nitrogen (TNN) and MDA activity, $r=0.849 ; r=0.815 ; r=0.672$, respectively. In Lake Miejskie, these dependencies were definitely lower. In this lake, positive significant correlation was noted only in the case of electrical conductivity and the activity of CAT $(r=0.732)$. At the same time, significantly negative correlation of this parameter with SOD activity was recorded $(r=-0.681)$.

The dependence of parameters characterizing the perch redox potential from both lakes can be described by means of two main components that explain this relationship to $97.5 \%$ (Fig. 2). The first main component provides explanation to $74.4 \%$ and the second to $23.1 \%$ a)

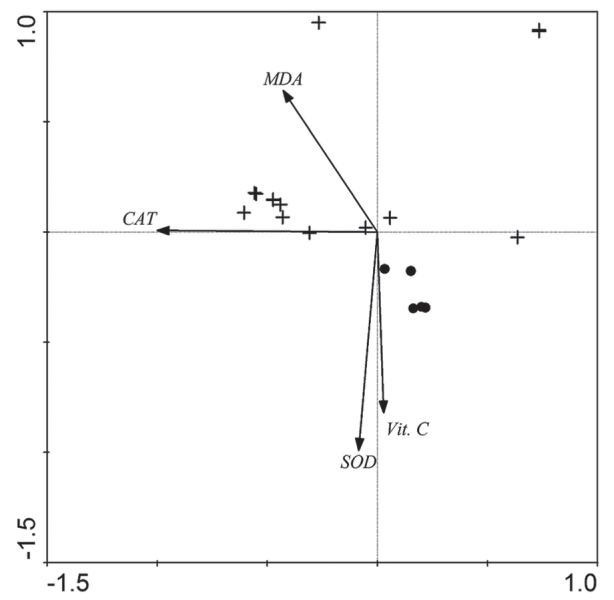

b)

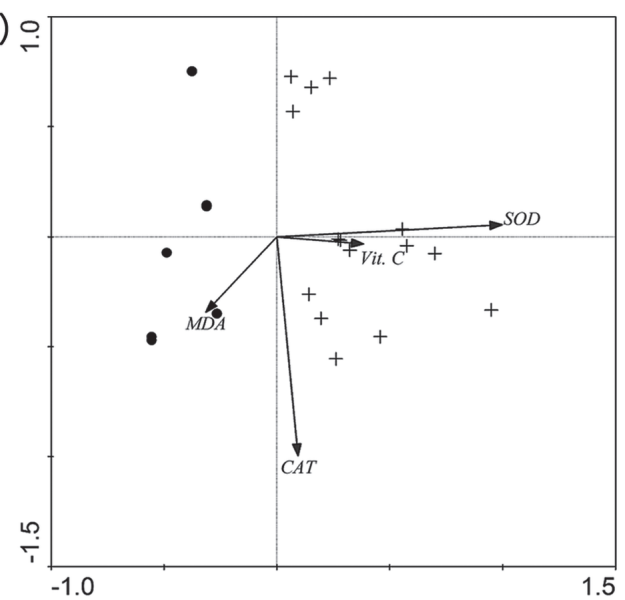

c)

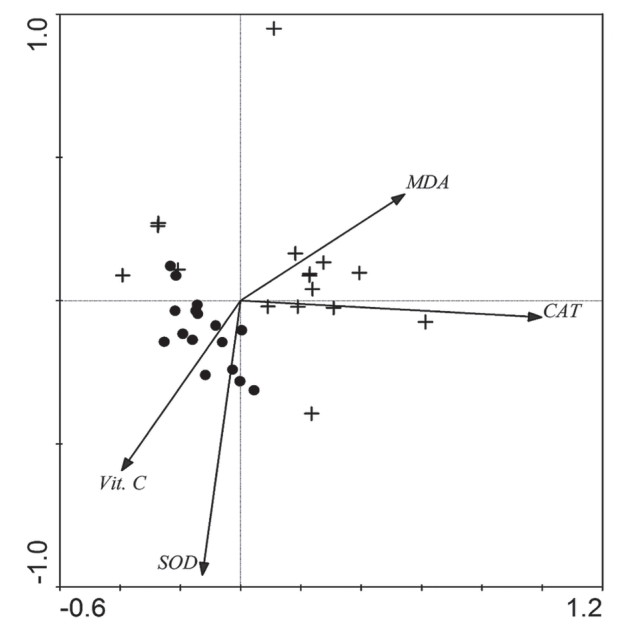

Fig. 2. Principal component analysis (PCA) of values of redox potential of perch (Perca fluviatilis L.)a), roach (Rutilus rutilus L.) b) and brown bullhead (Ameiurus nebulosus Le Sueur) c) from Syczyńskie Lake (+) and Miejskie Lake $(\bullet)$. 
of all dependencies. Herein, Axis 1 is negatively correlated with CAT activity, while Axis 2 negatively correlates two parameters with Vit. C and SOD activity. Axis 1 reveals a clear division of perch into two groups, i.e. populations from lakes with different trophy status (Fig. 2a).

The PCA analysis of the dependence of the redox potential parameters for roach revealed that two main components can be described to $93.8 \%$, of which the first component is at $59.5 \%$ and the second component is at $34.3 \%$ (Fig. 2b). Here, Vit. C content and the activity of SOD clearly correlate positively with Axis 1 , while CAT activity is negatively correlated with Axis 2. In the case of this species, there is also a clear division into two groups of fish of different trophy status (Axis 2) (Fig. 2b).

For the invasive species, brown bullhead, from both lakes, PCA analysis showed that the two main components explain this relationship to $92.8 \%$, the first and second components respectively being $76.0 \%$ and $16.85 \%$ (Fig. 2c). Axis 1 was positively correlated with CAT activity, while Axis 2 was negatively correlated with SOD activity. Unlike the perch and roach, none of the axes indicated brown bullhead division into groups due to the trophic diversity of the lakes (Fig. 2c).

The obtained results of the dependence of redox indicators on the physical and chemical parameters of water from the studied lakes are difficult to interpret. The high positive correlation was observed between the oxygen saturation of water $\left(\% \mathrm{O}_{2}\right)$ and MDA content and water temperature and vitamin $\mathrm{C}$ content, and the negative correlation between $\mathrm{O}_{2}$ and the content of Vit. C in Lake Syczyńskie may be related to the oxidation reaction of lipid compounds. The rate of this reaction increases significantly with increasing oxygen saturation and water temperature. Perhaps the factors that influenced the slowdown of the oxidation reaction in the lake include the presence of antioxidants and the lower temperature in the water reservoir in the studied period. It is known that the solubility of oxygen in water is inversely proportional to water temperature [63]. Furthermore, the positive correlation among nitrate nitrogen (NNO) and total nitrogen (TNN) and MDA content and negative between ammonium nitrogen $(\mathrm{NNH})$ and MDA content that we saw can be explained by the inflow of nitric compounds, especially nitrates, to the reservoirs. These compounds have a toxic effect on ichthyofauna, and fish can accumulate them to varying degrees in their body. In addition, ammonia is a strong poison that is lethal to fish and its concentration in water should not exceed $0.01 \mathrm{mg} \mathrm{L}^{-1}$, otherwise, it leads to physiological dysfunction [64]. The correlations of antioxidative enzymes activity (SOD and CAT) with electrical conductivity observed in Lake Miejskie may also indicate the high mineralization of the reservoir water $[65,66]$.

\section{Conclusions}

The results of the present study confirmed that oxidative stress in fish is mainly a consequence of the state of the environment in which they live and the degree of its contamination. In the muscles of studied fish species from lakes with different trophy status, there were differences in the concentration of muscle tissue redox indicators were obtained. This effect may indicate different sensitivity of individual fish species to the physicochemical parameters of the water, where more significant dependencies were noted in the case of hypertrophic Syczyńskie Lake. At the same time, compared to the fish from the eutrophic lake, the fish from the hypertrophic lake had worse quality parameters of the meat due to the greater intensity of oxidative processes. The obtained results are difficult to interpret unequivocally and further study would be indicated, taking into account the longer period and different times in the year in the functioning of the reservoir, as well as the specificity of fish species living in these conditions.

\section{Conflict of Interest}

The authors declare no conflict of interest.

\section{References}

1. MOHRI S.K., TOKUORI K., ENDO Y., FUJIMOTO K. Prooxidant activities in fish skin extracts and effects of some antioxidants and inhibitors on their activities. Fisheries Science, 65 (2), 269, 1999.

2. VELEZ-ALAVEZ M., MENDEZ-RODRIGUEZ L.C., MONTANEZ J.A.D. Vitamins $\mathrm{C}$ and $\mathrm{E}$ concentrations in muscle of elasmobranch and teleost fishes. Comparative Biochemistry and Physiology - Part A: Molecular \& Integrative Physiology, 170, 26, 2014.

3. GADZALA-KOPCIUCH R., BERECKA B. BARTOSZEWICZ J., BUSZEWSKI B. Some considerations about bioindicators in environmental monitoring. Polish Journal of Environmental Studies, 13 (5), 453, 2004.

4. RECHULICZ J., OGNIK K., GRELA E.R. The effect of adding protein-xanthophylls concentrate (PX) from lucerne (Medicago sativa) on growth parameters and redox profile in muscles of carp, Cyprinus carpio (L.). Turkish Journal of Fisheries and Aquatic Sciences, 14 (3), 697, 2014.

5. SAERA-VILA A.L., BENEDITO-PALOS A., SITJABOBADILLA J., NÁCHER-MESTRE J., SERRANO R., KAUSHIK S., PÉREZ-SÁNCHEZ J. Assessment of the health and antioxidant trade-off in gilthead sea bream (Sparus aurata L.) fed alternative diets with low levels of contaminants. Aquaculture, 296 (1-2), 87, 2009.

6. YONAR S.M., SAKIN F., YONAR M.E., ISPIR U., KIRICI M. Oxidative stress biomarkers of exposure to deltamethrin in rainbow Trout Fry (Oncorhynchus Mykiss). Fresenius Environmental Bulletin, 20 (8), 1931, 2011. 
7. FAZIO F., CECCHINI S., FAGGIO C., CAPUTO A. R., PICCIONE G. Stability of oxidative stress biomarkers in flathead mullet, Mugil cephalus, serum during short-term storage. Ecological Indicators, 46, 188, 2014.

8. PAŁCZYŃSKA-GUGUŁA K., TKACHENKO H., KURHALUK N. Bioaccumulation of elements and oxidative stress markers in the muscle tissue of smolts of sea trout (Salmo trutta L.) in the years 2009-2011. Słupskie Prace Biologiczne, 11, 149, 2014 [In Polish].

9. TAYLOR J.J., WILSON S.M., SOPINKA N.M., HINCH S.G., PATTERSON D.A., COOKE S.J., WILLMORE W.G. Are there intergenerational and population-specific effects of oxidative stress in sockeye salmon (Oncorhynchus nerka)? Comparative Biochemistry and Physiology - Part A: Molecular \& Integrative Physiology, 184, 97, 2015.

10. LING Q.F., HONG F.S. Antioxidative role of cerium against the toxicity of lead in the liver of silver crucian carp. Fish Physiology and Biochemistry, 36 (3), 367, 2010.

11. SEVCIKOVA M., MODRA H., SLANINOVA A., SVOBODOVA Z. Metals as a cause of oxidative stress in fish: a review. Veterinary Medicine, 56 (11), 537, 2011.

12. LORO V.L., JORGE M.B., DA SILVA K.R., WOOD C.M. Oxidative stress parameters and antioxidant response to sublethal waterborne zinc in a euryhaline teleost Fundulus heteroclitus: Protective effects of salinity. Aquatic Toxicology, 110-111, 187, 2012.

13. HĘŚ, M., KORCZAK J. The influence of different factors on the kinetics of the lipid oxidation in meat. Science Nature Technologies, 1, \#3, 2007.

14. RIFFEL A.P., GARCIA L.O., FINAMOR I.A., SACCOL E.M., MEIRA M., KOLBERG C., HORST A., PARTATA W., LLESUY S., BALDISSEROTTO B., PAVANATO M. A. Redox profile in liver of Leporinus macrocephalus exposed to different dissolved oxygen levels. Fish Physiology and Biochemistry, 38 (3), 797, 2012.

15. SILKINA N.I., MIKRYAKOV D.V., MIKRYAKOV V.R. Effect of anthropogenic pollution on oxidative processes in the liver of fish from the Rybinsk Reservoir. Russian Journal of Ecology, 43 (5), 386, 2012.

16. SHALIUTINA-KOLESOVA A., GAZO I., COSSON J., LINHART O. Comparison of oxidant and antioxidant status of seminal plasma and spermatozoa of several fish species. Czech Journal of Animal Science, 58 (7), 313, 2013.

17. 1RÜCKER J., WIEDNER C., ZIPPEL P. Factors controlling the dominance of Planktothrix agardhii and Limnothrix redekei in eutrophic shallow lakes. Hydrobiologia. 342/343, 107, 1997.

18. WIŚNIEWSKA M., KRUPA D., PAWLIKSKOWOROŃSKA B., KORNIJÓW R. Development of toxic Planktothrix agardhii (Gom.) Anagn. et Kom. and potentially toxic algae in the hypertrophic Lake Syczyńskie (Eastern Poland). Oceanological and Hydrobiological Studies, 36 (suppl.1), 173, 2007.

19. RECHULICZ J. Long-term changes of the fish community in a small hypertrophic lake. Polish Journal of Environmental Studies, 23 (3), 845, 2014.

20. HARASIMIUK M., MICHALCZYK Z., TURCZYŃSKI M. Łęczyńsko-Włodawskie lakes. Nature Monography. Biblioteka Monitoringu Środowiska, Lublin, 64, 176, 1998 [In Polish].

21. RECHULICZ J. Ichthyofauna of shallow Miejskie Lake one year after biomanipulation. TEKA Komisji Ochrony i Kształtowania Środowiska, 5, 117, 2008.

22. RECHULICZ J., PŁASKA W. Preliminary results of pikeperch, Sander lucioperca (L.), reproductive success one year after biomanipulation in a shallow lake. Komunikaty Rybackie, 1 (132), 1, 2013.

23. HERMANOWICZ W., DOŻAŃSKA W., DOLIDO J., KOZIOROWSKI B. Physical and chemical investigation methods of water and sewage. Arkady, Warsaw, 1976.

24. GOLTERMAN H.L. Methods for chemical analysis of fresh waters. IBP Handbook No. 8. Blackwell Scientific Publications, Oxford, Edinburgh, 467, 1969.

25. CEN DOCUMENT. Water quality - Sampling of fish with multi-mesh gillnets - EN 14757, 2005.

26. GREENWALD R.A. CRC handbook of methods for oxygen radical research. CRC Press, Michigan, 447, 1985.

27. BARTOSZ G. Second face of oxygen. Polish Scientific Publishers PWN, Warsaw, 448, 2004 [In Polish].

28. OMAYE S.T., TUMBULL J.D., SAUBERLICH H.E. Selected methods for determination of ascorbic acid in animal cells, tissues and fluids. Methods in Enzymology, 62, 3, 1979 .

29. SALIH M., SMITH D.M., PRICE J.F., DAWSON L.E. Modified extraction 2-thiobarbituric acid method for measuring lipid oxidation in poultry. Poultry Science, 66 (9), 1483, 1987.

30. CARVALHO C.D.S., BERNUSSO V.A., DE ARAÚJO H.S., ESPÍNDOLA E.L., Fernandes M. N. Biomarker responses as indication of contaminant effects in Oreochromis niloticus. Chemosphere, 89 (1), 60, 2012.

31. FLIK G., KLAREN P.H.M., VAN DEN BURG E.H., METZ J.R., HUISING M.O. CRF and stress in fish. General and Comparative Endocrinology, 146, 36, 2006.

32. TINOS A., GESTO M., MIGUEZ J.M., SOENGAS J.L. Naphthalene treatment alters liver intermediary metabolism and levels of steroid hormones in plasma of rainbow trout (Oncorhynchus mykiss). Ecotoxicology and Environmental Safety, 66, 139, 2007.

33. FUZZEN M.L.M., VAN DER KRAAK G., BERNIER N.J. Stirring up new ideas about the regulation of the hypothalamic-pituitary-interrenal axis in zebrafish (Danio rerio). Zebrafish, 7 (4), 349, 2010.

34. VAN DER OOST R., BEYER J., VERMEULEN N.P.E. Fish bioaccumulation and biomarkers in environmental risk assessment: a review. Environmental Toxicology and Pharmacology, 13 (2), 57, 2003.

35. NURMINEN L., HELLÉN N., OLIN M., TIAINEN J., VINNI M., GRÖNROOS M., ESTLANDER S., HORPPILA J., RASK M., LEHTONEN H. Fishinginduced changes in predation pressure by perch (Perca fluviatilis) regulate littoral benthic macroinvertebrate biomass, density, and community structure. Aquatic Ecology, 52, 1, 2018.

36. RECHULICZ J., PŁASKA W. Inter-population variability of diet of the alien species brown bullhead (Ameiurus nebulosus) from lakes with different trophic status. Turkish Journal of Fisheries and Aquatic Sciences, 19 (1), 59, 2019.

37. RECHUliCZ J., PŁASKA W. The invasive Ameiurus nebulosus as a permanent part of the fish fauna in selected reservoirs in Central Europe: long term study of three shallow lakes. Turkish Journal of Zoology, 42, 464, 2018.

38. MEYER J.N., NACCI D.E., DI GIULIO R.T. Cytochrome P4501A (CYP1A) in Killifish (Fundulus heteroclitus): Heritability of altered expression and relationship to survival in contaminated sediments. Toxicological Sciences, 68, 69, 2002.

39. TOPOROWSKA M., PAWLIK-SKOWOROŃSKA B., KRUPA D., KORNIJÓW R. Winter versus summer blooming of phytoplankton in a shallow lake: effect of 
hypertrophic conditions. Polish Journal of Ecology, 58 (1), 3, 2010.

40. ADAMCZYK W., JACHIMOWSKI A. Impact of biogenic components on quality and eutrophication of flowing surface waters constituting the source of drinking water for the city of Kraków. Food. Science Technology. Quality, 6 (91), 175, 2013 [In Polish].

41. KULESZA P., BAŁAGA K. Reconstruction of palaeoenvironmental changes in the area of Lake Syczyńskie on the basis of palaeoecological analyses. Annales Universitatis Mariae Curie-Skłodowska, sec. B, 70 (1), 39, 2015 [In Polish].

42. KORNIJÓW R., SMAL H., PĘCZUŁA W., LORENS B., RECHULICZ J., SUGIER P., PALEOLOG-DEMETRAKI A., LIGĘZA S., TARKOWSKA-KUKURYK M., KOWALCZYK D., SZAFRAN K., HALKIEWICZ A. Hypertrophication of Lake Syczyńskie (Eastern Poland). Limnological Review, 2, 209, 2002.

43. SOLIS M. Impact of Wieprz-Krzna canal on physicalchemical and biological characteristics in selected storage reservoirs. Journal of Ecological Engineering, 29, 182, 2012 [In Polish].

44. PAJEWSKI T. Water pollution as a negative effect of agricultural activities. Roczniki Naukowe Stowarzyszenia Ekonomistów Rolnictwa i Agrobiznesu, 18, 191, 2016 [In Polish].

45. KOVACIK A. Oxidative stress in fish induced by environmental pollutants. Journal of Animal Science and Biotechnology, 50 (1), 121, 2017.

46. MOHANTY D., SAMANTA L. Multivariate analysis of potential biomarkers ofoxidative stress in Notopterus notopterus tissues from Mahanadi River as afunction of concentration of heavy metals. Chemosphere, 155, 28, 2016.

47. ABDEL-MONEIM A.M., ESSAWY A.E., BADR EL-DIN N.K., EL-NAGGAR N.M. Biochemical and histopathological changes in liver of the Nile tilapia from Egyptian polluted lakes. Toxicology and Industrial Health, 32 (3), 457, 2016.

48. KAPTANER B., KANKAYA E., DOGAN A., DURMUS A. Alterations in histology andantioxidant defense system in the testes of the lake Van fish (Alburnus tarichi Güldenstädt, 1814). Environmental Monitoring and Assessment, 188 (8), 1, 2016.

49. EL-GAZZAR A.M., ASHRY K.E., EL-SAYED Y.S. Physiological and oxidative stress biomarkers in the freshwater Nile tilapia, Oreochromis niloticus L., exposed to sublethal doses of cadmium. Alexandria Journal of Veterinary Sciences, 40, 29, 2014.

50. KAYA H., AKBULUT M. Effects of waterborne lead exposure in Mozambique tilapia: oxidative stress, osmoregulatory responses, and tissue accumulation. Journal of Aquatic Animal Health, 27 (2), 77, 2015.

51. KURHALYUK N., TKACHENKO H., PAŁCZYŃSKA $\mathrm{K}$. Antioxidant enzymes profile in the brown trout (Salmo trutta trutta) with ulcerative dermal necrosis. Bulletin of the Veterinary Institute in Pulawy, 53, 813, 2009.

52. CISZEWSKI D., ALEKSANDER-KWATERCZAK U., POCIECHA A., SZAREK-GWIAZDA E., WALOSZEK A., WILK-WOŹNIAK E. Small effects of a large sediments contamination with heavy metals on aquatic organisms in the vicinity of an abandoned lead and zinc mine. Environmental Monitoring and Assessment, 185 (12), 9825, 2013.
53. BLUMER L.S. The significance of biparental care in the brown bullhead, Ictalurus nebulosus. Environmental Biology of Fishes, 12 (3), 231, 1985.

54. PYRON M., OBERT E.C., WELLINGTON R. Tumor rates and population estimates of brown bullhead (Ameiurus nebulosus) in Presque Isle Bay, Lake Erie. Journal of Great Lakes Research, 27 (2), 185, 2001.

55. MACEDA-VEIGA A., MAC NALLY R., DE SOSTOA A. The presence of non-native species is not associated with native fish sensitivity to water pollution in greatly hydrologically altered rivers. Science of the Total Environment, 607-608, 549, 2017.

56. SMAL H., KORNIJÓW R., LIGĘZA S. The effect of catchment on water quality and eutrophication risk of five shallow lakes (Polesie region, Eastern Poland). Polish Journal of Ecology, 53 (3), 313, 2005.

57. GAMBUŚ F., WIECZOREK J. Pollution of fertilizers with heavy metals. Ecological Chemistry and Engineering A, 19 (4-5), 353, 2012.

58. HERMENEAN A., DAMACHE G., ALBU P., ARDELEAN A., ARDELEAN G., ARDELEAN D.P., HORGE M., NAGY T., BRAUN M., ZSUGA M., KÉKI S., COSTACHE M., DINISCHIOTU A. Histopatological alterations and oxidative stress in liver and kidney of Leuciscus cephalus following exposure to heavy metals in the Tur River, North Western Romania. Ecotoxicology and Environmental Safety, 119, 198, 2015.

59. STOLIAR O.B., LUSHCHAK V.I. Environmental pollution and oxidative stress in fish. Oxidative stress. Environmental Induction and Dietary Antioxidants. Croatia. 131, 2012.

60. ANJUM S.A., JIAN-HANG N., RAN W. Regulation mechanism of exogenous 5-aminolevulinic acid on growth and physiological characters of Leymus chinensis (Trin.) under high temperature stress. Philippine Agricultural Scientist, 99 (3), 253, 2016.

61. MCFARLAND V.A., INOUYE L.S., LUTZ C.H., JARVIS A.S., CLARKE J.U., MCCANT D.D. Biomarkers of oxidative stress and genotoxicity in livers of fieldcollected brown bullhead Ameiurus nebulosus. Archives of Environmental Contamination and Toxicology, 37 (2), 236, 1999.

62. SHEN H., SONG C., ZHEN F.F., WANG F., REN $\mathrm{H}$. Enzymatic biomarker measurement and study on pollution-induced antioxidant enzyme responses in freshwater fish liver, Brocarded carp. Proceedings of 1st International Conference on Bioinformatics and Biomedical Engineering. 90, 2007.

63. DĄBROWSKA M.A, ZIELIŃSKA A., NOWAK I. Lipid oxidation products as a potential health and analytical problem. Chemik, 69 (2), 89, 2015.

64. DOLOMATOV S., ZUKOW W., SKOMAROVSKIY D.V. Features nitrogen metabolism fish and methods neutralize the product of nitrogen metabolism fish aquaculture. Journal of Health Sciences, 1 (3), 13, 2011.

65. VERMA P., CHANDAWAT D., GUPTA U., SOLANKI H. Water quality analysis of an organically polluted lake by investigating different physical and chemical parameters. International Journal of Research in Chemistry and Environment, 2 (1), 105, 2012.

66. KASZA H. The study on specific electrical conductivity of water precipitation in Bielsko-Biała region. Journal of Ecological Engineering, 41, 166, 2015 [In Polish]. 